J. Chosun Natural Sci.

Vol. 7, No. 3 (2014) pp. $188-192$

http://dx.doi.org/10.13160/ricns.2014.7.3.188

\title{
Determination of Cobalt(III) Ion Using a Nafion-Ethylenediamine Modified Glassy Carbon Electrode
}

\author{
Seok Jin Kim ${ }^{1}$ and Young Chun $\mathrm{Ko}^{2 \dagger}$
}

\begin{abstract}
Determination of cobalt(III) ion with a perfluorinated sulfonated polymer-ethylenediamine (nafion-en) modified glassy carbon electrode is studied. It is based on the chemical reactivity of an immobilized layer, nafion-en, to yield complex $\left[\mathrm{Co}(\mathrm{en})_{3}\right]^{3+}$. The reduction peak potential by differential pulse voltammetry (DPV) is observed at $-0.437 \pm 0.047 \mathrm{~V}(\mathrm{vs} . \mathrm{Ag} /$ $\mathrm{AgCl})$. The linear calibration curve is obtained in cobalt(III) ion concentration range $1.0 \times 10^{-8} \sim 1.0 \times 10^{-3} \mathrm{M}\left(5.893 \times 10^{-12} \sim\right.$ $\left.5.893 \times 10^{-5} \mathrm{~g} / \mathrm{mL}\right)$.
\end{abstract}

Key words: Cobalt(III) Ion, Nafion-Ethylenediamine Modified Glassy Carbon Electrode, Differential Pulse Voltammetry

\section{Introduction}

As the secondary industry is highly developed, the life of human became rich. By these causes, serious environmental pollution are threatening the survival of the human race. Hazardous materials are more and more concentrated in the higher organisms owing to bioaccumulation by the process of the food chain in the ecosystem $^{[1]}$. Due to this phenomenon, many people have been exposed to various diseases.

The study to determine cobalt, chromium, copper, and nickel in oral mucosa cells was achieved by inductively coupled plasma mass spectrometry. The method has been suitably validated and the regression equation was established in the linear range of $2.0 \sim 100.0 \mathrm{ng} / \mathrm{mL}$ for their elements ${ }^{[2]}$. The repeatability of the $\mathrm{Ni}(\mathrm{II})$ and $\mathrm{Co}$ (II) adsorptive stripping voltammetric signals obtained at the lead film screen-printed electrode were equal to $4 \%$ and $3 \%$ up to 10 times, respectively. The limits of detection established for simultaneous determination of $\mathrm{Ni}$ and $\mathrm{Co}$ for $90 \mathrm{sec}$ of accumulation time were each 0.2 and $0.3 \mu \mathrm{g} / \mathrm{L}^{[3]}$. The each detection limit of $\mathrm{Cd}, \mathrm{Co}$, and $\mathrm{Ni}$, and $\mathrm{Pb}$ was measured to 0.005 , $0.015,0.015$, and $0.073 \mathrm{mg} / \mathrm{g}$ by flame atomic absorp-

\footnotetext{
${ }^{1}$ Suncheon Hyosan High School, Chonnam 540-957, Korea

${ }^{2}$ Graduate School of Education, Sehan University, Chonnam 526-702, Korea

†Corresponding author: ycko@sehan.ac.kr

(Received: May 2, 2014, Revised : September 22, 2014,

Accepted :September 25, 2014)
}

tion spectrometry. It was found that $\mathrm{Cd}, \mathrm{Co}$ and $\mathrm{Pb}$ were under detection limits in nine honeys, while $\mathrm{Ni}$ was determined at the level of $0.19 \sim 0.93 \mathrm{mg} / \mathrm{g}^{[4]}$. The effect of polyethylene glycols with molecular weights of $2000,6000,13000$, and 20000 on the sensitivity of the thermal lens determination of cobalt(III) using nitrosoR-salt and 2-nitroso-1-naphthol was studied. At the polymer concentration as low as $10 \%$, the sensitivity coefficient was increased significantly and the detection limit was decreased by a factor of 1.5 2 with respect to the determination in an aqueous medium without polyethylene glycol ${ }^{[5]}$. The $\mathrm{pH}$ of the analyte solution, the amount of graphene oxide, the sample volume, the contact time between analytes and sorbent (stirring time), and the effects of foreign metals were discussed. The proposed procedure allowed them to obtain the detection limits of $0.5,0.7,1.5,1.8$ and $1.4 \mathrm{ng} / \mathrm{mL}$ for $\mathrm{Co}(\mathrm{ii})$, $\mathrm{Ni}(\mathrm{ii}), \mathrm{Cu}(\mathrm{ii}), \mathrm{Zn}$ (ii), and $\mathrm{Pb}(\mathrm{ii})$, respectively. The linearity of the method was in the range of $5 \sim 100 \mathrm{ng} / \mathrm{mL}^{[6]}$. The study on the simultaneous determination of $\mathrm{Ni}$ (II) and $\mathrm{Co}$ (II) dimethylglyoximates through adsorptive cathodic stripping voltammetry at an in situ bismuthmodified gold electrode was reported. The key operational parameters, such as $\mathrm{Bi}(\mathrm{III})$ concentration, accumulation potential and accumulation time were optimized and the morphology of the Bi-microcrystals deposited on the Au-electrode was studied. The calculated limit of detection was $40 \mathrm{ng} / \mathrm{L}$ for $\mathrm{Ni}(\mathrm{II})$ alone, whereas that was $98 \mathrm{ng} / \mathrm{L}$ for $\mathrm{Ni}(\mathrm{II})$ and $58 \mathrm{ng} / \mathrm{L}$ for 
Co(II), when both metal ions were measured together ${ }^{[7]}$. The procedure on the voltammetric determination of cobalt was achieved by an adsorptive accumulation of cobalt pyrogallol red complex on a stationary mercury drop electrode, followed by cathodic stripping voltammetry measurement of the reduction current of the adsorbed complex at $-1.17 \mathrm{~V}(v s$. $\mathrm{Ag} / \mathrm{AgCl})$. The optimum conditions for the determination of cobalt were performed under the conditions of $\mathrm{pH} 11.0$ and $35 \mu \mathrm{M}$ pyrogallol red, an accumulation potential of $-0.9 \mathrm{~V}$, and scan rate $80 \mathrm{mV} / \mathrm{s}$. The peak current was proportional to the concentration of cobalt over the concentration range 5.0 to $280 \mathrm{ng} / \mathrm{mL}$ with a detection limit of $1 \mathrm{ng} /$ $\mathrm{mL}$ and an accumulation time of $140 \mathrm{sec}^{[8]}$. Cobalt(II) formed a pink coloured complex with nicotinohydroxamic acid in borate buffer medium of $\mathrm{pH}$ 9.2. Under optimum conditions, the maximum absorption of the complex was measured at $610 \mathrm{~nm}$. The Beer's law was obeied in the range of 0.65 to $5.9 \mu \mathrm{g} / \mathrm{mL}$ of cobalt(II). The molar absorptivity and the Sandell's sensitivity of the complex were $7.038 \times 104 \mathrm{~L} / \mathrm{mol} \cdot \mathrm{cm}$ and $0.0065 \mu \mathrm{g} / \mathrm{cm}^{2} \cdot 0.001 \mathrm{~A}$, respectively ${ }^{[9]}$.

As the concentration of environmental pollution substance is quantified easily, identification of environmental pollution situation, and countermeasures to prevent environmental pollution can be established. Much water has been contaminated by cobalt as that is used especially in various fields such as semiconductors, ceramics, steel smelting, aerospace, and industrial batteries. A quantitative methods of cobalt(II) have been studied by many people recently. But ones of cobalt(III) ion have not been done in almost. Therefore, in this study, cobalt (III) ions would be quantified by DPV.

\section{Experimental Section}

\subsection{Reagents}

$0.10 \mathrm{M} \mathrm{Co}$ (III) ion stock solution was prepared by dissolving a required amount of cobalt(III) fluoride (Sigma-Aldrich) in $\mathrm{pH}=1.0$ buffer solution. Nafion and en were purchased from Sigma-Aldrich, and used without further purification. Chemicals for making each buffer solution of $\mathrm{pH}=0.0,0.7,1.0,1.3,2.0,3.0$ and 4.0 prepared by method of CRC handbook, and the other ones were purchased from Sigma-Aldrich and used without further purification as analytical grade. Distilled water generated with Millipore Co. (France; serial no.:
F6KM12658T) was used throughout the all experiments.

\subsection{Instruments}

DPV was performed using CHI model 610A electrochemical analyzer (USA) and the results were plotted with a printer. The electrochemical cell includes a $\mathrm{Pt}$ wire auxiliary electrode and $\mathrm{CHI} 111 \mathrm{Ag} / \mathrm{AgCl}$ reference electrode. All potentials presented in this work are referenced to the electrode.

\subsection{Working Electrode}

The working electrode used in this DPV experiment is consisted of a $7.07 \mathrm{~mm}^{2}$ glassy carbon disk. $5 \%$ nafion solution is made of $2 \%$ nafion solution as diluted by ethanol, which is used as a modifier. To make nafion-en electrode containing each the fixed en concentration, those prepared solutions were dropped on the surface of the clear glassy carbon electrode with a $1 \mu \mathrm{L}$ respectively, and then the ethanol solvent was evaporated in the air. After the ethanol had evaporated, the coated layer on the electrode surface was dried for $60 \mathrm{sec}$ by a dryer. The working electrode was grinded by the suspended solution having $0.05 \mu \mathrm{m}$ gamma-alumina powder prior to its coat. After washing with distilled water, the electrode was washed for about 1 minute by ultrasonic cleaner to remove the solid particles on the electrode surface. Thereafter, the electrode was washed with distilled water and dried in air and used.

2.4 Experimental Methods and Stability of Nafion-en Modified Glassy Carbon Electrode

Preconcentration was performed by immersing chemically modified electrode for 10 minutes in buffer solution of $\mathrm{pH} 1.0$ containing the $\mathrm{Co}$ (III) ion. After that, the electrode was scanned cathodically from 0.0 to $-1.0 \mathrm{~V}$, and the peak current was measured by the usual way. The pulse amplitude in DPV was $50 \mathrm{mV}$ and the potential scan rate was $20 \mathrm{mV} / \mathrm{sec}$. After the DPV experiment, The electrode was stirred by magnetic stirrer in $0.1 \mathrm{M} \mathrm{HCl}$ solution for 15 minutes, and then washed with double distilled water and re-washed with the buffer solution. And the electrode surface was reproduced. Confirmation of the fact for removal of $\mathrm{Co}$ (III) ion from the surface of the electrode could know by looking at differential pulse voltammetric curve drawn 
Table 1. Effect of differential pulse peak current and potential with a change of the number of renewed electrode successively in $\mathrm{pH} 1.0$ buffer solution containing $1.0 \times 10^{-4} \mathrm{M}$ $\mathrm{Co}(\mathrm{III})$ ion. Preconcentration time $10 \mathrm{~min}$

\begin{tabular}{ccc}
\hline $\begin{array}{c}\text { Number of } \\
\text { renewed electrode }\end{array}$ & $\begin{array}{c}\text { Peak Current } \\
(\mu \mathrm{A})\end{array}$ & $\begin{array}{c}\text { Peak potential }(\mathrm{V}) \\
\text { vs. } \mathrm{Ag} / \mathrm{AgCl}\end{array}$ \\
\hline 0 & 4.33 & -0.427 \\
1 & 4.13 & -0.427 \\
2 & 3.68 & -0.423 \\
3 & no observed & $\times$ \\
4 & no observed & $\times$ \\
\hline
\end{tabular}

for the renewed electrode. That is, no peak is seen in the scan range. $1.0 \times 10^{-4} \mathrm{M} \mathrm{Co}$ (III) ion is quantified by DPV to see whether or not the renewed electrode as above is used continuously and to investigate the stability of the electrode in a buffer solution of $\mathrm{pH} 1.0$ (see Table 1). As number of the renewed electrode is increased, the reduction peak potential shifts to a positive direction and the peak current decreases. Therefore as the number of the renewed electrode for nafion-en modified electrode is increased, it can be seen that the electrodes becomes unstable. In standard solution of $1.0 \times 10^{-4} \mathrm{M} \mathrm{Co}$ (III) ion, the peak current of once and twice renewed electrode is decreased by 4.6 and $15.0 \%$, respectively. And the peak current of thrice or more cases could not be observed. When number of the renewed electrode is only once, detection of $\mathrm{Co}(\mathrm{III})$ ion is measured within a relative error range of $5 \%$.

\section{Results and Discussion}

\subsection{Optimal Composition of a Chemical Modified}

\section{Electrode}

\subsubsection{Effect of $\mathrm{pH}$}

When trying to quantify $\mathrm{Co}$ (III) ion by using nafionen electrode, the $\mathrm{pH}$ of each buffer solution containing $1.0 \times 10^{-4} \mathrm{M} \mathrm{Co}(\mathrm{III})$ ion is changed from 0.0 to 4.0 in order to determine the optimum $\mathrm{pH}$ used as the supporting electrolyte. $\mathrm{Co}$ (III) ion is preconcentrated for 15 minutes in each buffer solution of $\mathrm{pH} 0.0,0.7,1.0$. 1.3, 3.0, and 4.0 for nafion-en modified glassy carbon electrode, after which potential is supplied from $0.0 \mathrm{~V}$ to $-1.0 \mathrm{~V}$ to get a cathodic peak current of $\left[\mathrm{Co}(\mathrm{en})_{3}\right]^{3+}$ in each buffer solution. And as a result, plot of the peak current $\left(i_{\mathrm{p}}\right)$ vs. the potential is shown in Fig. 1. As seen in Fig. 1, the peak current shows the largest value in

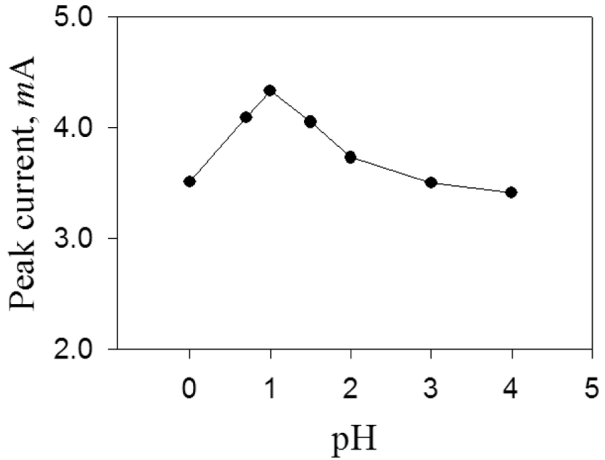

Fig. 1. Dependence of differential pulse peak current for $\mathrm{pH}$ variation containing $1.0 \times 10^{-4} \mathrm{M} \mathrm{Co}$ (III) ion at a nafionen modified electrode. Preconcentration time $15 \mathrm{~min}$; Scan rate $20 \mathrm{mV} / \mathrm{sec}$; Pulse amplitude $50 \mathrm{mV}$.

buffer solution of $\mathrm{pH}$ 1.0. And so, in this paper the experimental conditions of the buffer solution to qualify $\mathrm{Co}$ (III) ion is fixed to $\mathrm{pH} 1.0$. On the other hand, as $\mathrm{pH}$ of the solution is changed, cathodic peak potential changes. At this time the smaller $\mathrm{pH}$ of the solution is, the cathodic peak current of $\left[\mathrm{Co}(\mathrm{en})_{3}\right]^{3+}$ is shifted to a negative direction. That is, as $\mathrm{pH}$ of the solution is decreased, the stability of $\mathrm{Co}$ (III)-en complex increases.

\subsubsection{Effect of en Concentration}

As a reductive response current of $1.0 \times 10^{-4} \mathrm{M} \mathrm{Co}$ (III) ion is measured, the experiments to find optimum concentration conditions of en to fix in nafion are done in the range of $1.0 \times 10^{-3} \mathrm{M}$ to $5.0 \times 10^{-3} \mathrm{M}$ en. After preconcentration of $\mathrm{Cu}$ (III) ion for 15 minutes in a solution

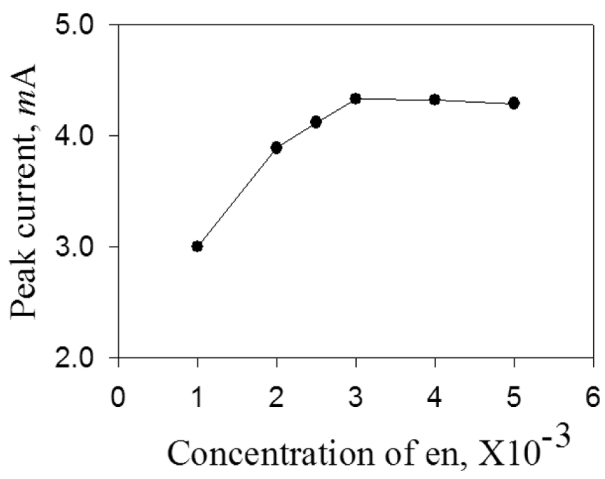

Fig. 2. Dependence of differential pulse peak current for a change of en concentration in $\mathrm{pH} 1.0$ buffer solution containing $1.0 \times 10^{-4} \mathrm{M} \mathrm{Co}(\mathrm{III})$ ion. Preconcentration time $15 \mathrm{~min}$; Scan rate $20 \mathrm{mV} / \mathrm{sec}$; Pulse amplitude $50 \mathrm{mV}$. 
of $1.0 \times 10^{-4} \mathrm{M} \mathrm{Cu}$ (III) ion, the peak current was measured at $0.437 \mathrm{~V} \pm 0.033 \mathrm{~V}$ using of each electrode made under the above conditions. And the measurement results are plotted in Fig. 2. The peak current is increased with the concentration of en as shown in Fig. 2 , but the peak current does not increase any more when that is reached at $4.0 \times 10^{-3} \mathrm{M}$ en. And so in this experiment, the optimum condition of electrode composition is determined to solution of $2 \%$ nafion containing $4.0 \times 10^{-3} \mathrm{M}$ en.

\subsubsection{Effect of Preconcentration Time}

When trying to quantify $\mathrm{Co}$ (III) ion by using nafionen electrode, the following experiment is performed to determine the optimum condition of preconcentration time. Differential pulse voltammetry is performed by change of preconcentration time in buffer solution of pH 1.0 containing $1.0 \times 10^{-4} \mathrm{M} \mathrm{Co}(\mathrm{III})$ ion. That is, preconcentration time of nafion-en modified electrode is varied from 3 to 30 minutes in $10 \mathrm{~mL}$ the sample solution. After that potential is supplied from $0.0 \mathrm{~V}$ to $-1.0 \mathrm{~V}$ to get the cathodic peak current of $\left[\mathrm{Co}(\mathrm{en})_{3}\right]^{3+}$ in buffer solution of $\mathrm{pH} 1.0$ containing $1.0 \times 10^{-4} \mathrm{M} \mathrm{Co}$ (III) ion. And the measurement results are plotted in Fig. 3. The peak current is increased with preconcentration time as shown in Fig. 3, but the peak current does not increase any more when that is reached at 15 minutes. Therefore in this experiment, the optimum condition of preconcentration time is determined to 15 minutes in buffer solution of $\mathrm{pH} 1.0$ containing $1.0 \times 10^{-4} \mathrm{M} \mathrm{Co}$ (III) ion.

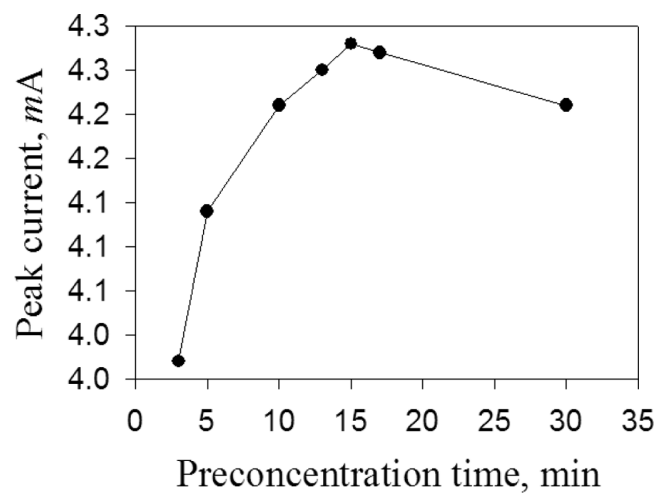

Fig. 3. Dependence of differential pulse voltammetric response for the preconcentration time in $\mathrm{pH} 1.0$ buffer solution containing $1.0 \times 10^{-4} \mathrm{M} \mathrm{Co}(\mathrm{III})$ ion. Preconcentration time $15 \mathrm{~min}$; Scan rate $20 \mathrm{mV} / \mathrm{sec}$; Pulse amplitude $50 \mathrm{mV}$.
3.2. Quantification of $\mathrm{Co}$ (III) lon by Differential Pulse Voltammetry Using Nafion-en Modified Electrode

By using optimal conditions determined by the above experiments, differential pulse voltammograms for different concentration of $\mathrm{Co}$ (III) ion in buffer solution of $\mathrm{pH}=1.0$ are shown in Fig. 4. And as the result, for the standard curve a plot of the cathodic peak current vs. $\log [\mathrm{Co}(\mathrm{III})$ ion $]$ is obtained in Fig. 5.

\subsection{Effect of Interfering lons}

When $\mathrm{Co}$ (III) ion is quantified by the above experi-

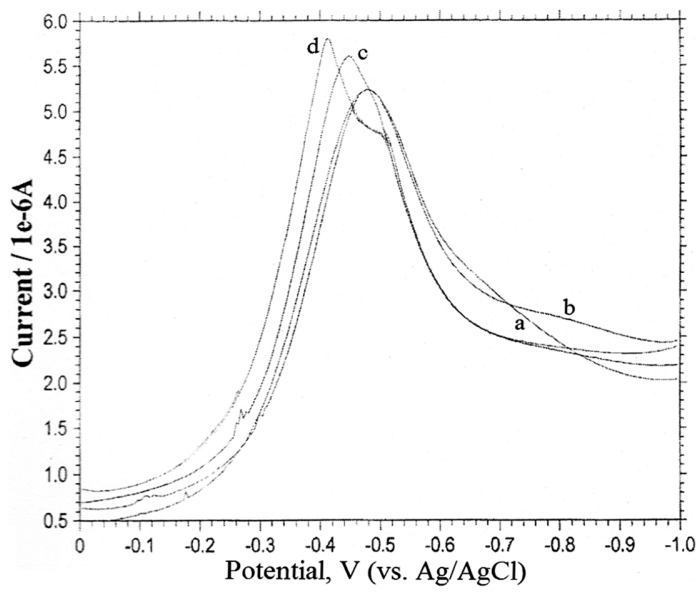

Fig. 4. Differential pulse voltammograms for different concentration of $\mathrm{Co}$ (III) ion in $\mathrm{pH} 1.0$ buffer solution, (a) 0 (nafion-en modified), (b) $1.0 \times 10^{-8}$, (c) $1.0 \times 10^{-5}$, and (d) $1.0 \times 10^{-3} \mathrm{M} \mathrm{Co}$ (III) ion. Scan rate $20 \mathrm{mV} / \mathrm{sec}$; Pulse amplitude $50 \mathrm{mV}$.

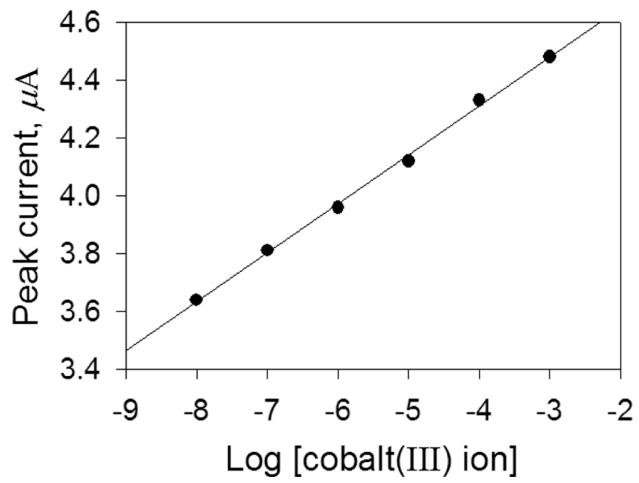

Fig. 5. Standard calibration curve for determination of Co(III) ion at a nafion-en modified electrode by differential pulse voltammogram in $\mathrm{pH} 1.0$ buffer solution. Scan rate $20 \mathrm{mV} / \mathrm{sec}$; Pulse amplitude $50 \mathrm{mV}$. 
ments, cathodic peak current using differential pulse voltammetry is measured to know effect of interfering ions, and the relative error is calculated. A peak current by addition of each $1.0 \times 10^{-4} \mathrm{M} \mathrm{Fe}^{2+}, \mathrm{Mn}^{2+}$, and $\mathrm{Ni}^{2+}$ in buffer solution of $\mathrm{pH} 1.0$ containing $1.0 \times 10^{-4} \mathrm{M} \mathrm{Co}$ (III) ion has brought a decrease of $13.7,15.2$, and $18.3 \%$. But the peak current by addition of $1.0 \times 10^{-4} \mathrm{M} \mathrm{Cu}^{2+}$ has brought one of $4.75 \%$. Thus, ions such as each $\mathrm{Fe}^{2+}$, $\mathrm{Mn}^{2+}$, and $\mathrm{Ni}^{2+}$ interfere considerably to the determination of $\mathrm{Co}$ (III) ion. But $\mathrm{Cu}^{2+}$ is found to does interfere to the determination of that within relative error of less than $5 \%$. Interference effects is presented greatly because en in nafion-en modified electrode forms complex with each $\mathrm{Fe}^{2+}, \mathrm{Mn}^{2+}$, and $\mathrm{Ni}^{2+}$.

\section{Conclusions}

The optimum conditions for the determination of $\mathrm{Co}$ (III) ion are performed under the conditions of $\mathrm{pH}$ $1.0,4.0 \times 10^{-3} \mathrm{M}$ of ethylenediamine, preconcentration time of 15 minutes. The peak current is proportional to the concentration of $\log [\mathrm{Co}$ (III) ion] in the concentration range of $1.0 \times 10^{-8}$ to $1.0 \times 10^{-3} \mathrm{M}\left(5.893 \times 10^{-12} \sim\right.$ $\left.5.893 \times 10^{-5} \mathrm{~g} / \mathrm{mL}\right)$.

\section{Acknowledgments}

This research was supported in part by research funds from Sehan University, 2014.

\section{References}

[1] E.-K. Kim, Y.-K. Cho, Y.-D. Kwon, M.-A Park, H.S. Kim, and K.-H. Park, "Study on adsorption and recovery of heavy metal ions, $\mathrm{Cd}(\mathrm{II})$ and $\mathrm{Pb}$ (II), by chitin", Anal. Sci. \& Tech., Vol. 15, pp. 163-171, 2002.

[2] A. Martín-Cameán, A. Jos, A. Calleja, F. Gil, A. Iglesias-Linares, E. Solano, and A. M. Cameán, "Development and validation of an inductively coupled plasma mass spectrometry (ICP-MS) method for the determination of cobalt, chromium, copper and nickel in oral mucosa cells", Microchem. J., Vol. 114, pp. 73-79, 2014.

[3] A. Bobrowski, A. Królicka, M. Maczuga, and J. Zarębski, "A novel screen-printed electrode modified with lead film for adsorptive stripping voltammetric determination of cobalt and nickel", Sen. Actu. B: Chem., Vol. 191, pp. 291-297, 2014.

[4] H. Stecka, D. Jedryczko, P. Pohl, and M. Welna, "Pre-concentration of traces of cadmium, cobalt, nickel and lead in natural honeys by solid phase extraction followed by their determination using flame atomic absorption spectrometry", J. Brazilian Chem. Soci., Vol. 25, pp. 331-339, 2014.

[5] E. S. Ryndina, M. A. Proskurnin, A. A. Zhirkov, and V. M. Shkinev, "Effect of polyethylene glycols on the sensitivity of the thermal lens determination of cobalt with nitrosonaphthols of various structures (nitroso-R-salt and 2-nitroso-1-naphthol)", J. Anal. Chem., Vol. 69, pp. 136-142, 2014.

[6] B. Zawisza, R. Sitko, E. Malicka, and E. Talik, "Graphene oxide as a solid sorbent for the preconcentration of cobalt, nickel, copper, zinc and lead prior to determination by energy-dispersive X-ray fluorescence spectrometry", Anal. Meth., Vol. 5, pp. 6425-6430, 2013.

[7] A. Mardegan, S. DalBorgo, P. Scopece, L. M. Moretto, S. B. Hocevar, and P. Ugo, "Simultaneous adsorptive cathodic stripping voltammetric determination of nickel(II) and cobalt(II) at an in situ bismuth-modified gold electrode", Electroanal., Vol. 25, pp. 2471-2479, 2013.

[8] F. Hasanpour, H. Teimori, M. Fouladgar, and M. Taei, "Trace and selective determination of cobalt(II) in water and salt samples using cathodic adsorptive stripping voltammetry in the presence of pyrogallol red", J. Serbian Chem. Soci., Vol. 78, pp. 717-724, 2013.

[9] R. Muthuselvi, "Direct spectrophotometric determination of cobalt(II) with nicotinohydroxamic acid in aqueous medium”, J. Indian Chem. Soc., Vol. 90, pp. 923-927, 2013. 